Check for updates

Cite this: RSC Adv., 2019, 9, 9041

Received 21st December 2018

Accepted 7th March 2019

DOI: $10.1039 / c 8 r a 10465 d$

rsc.li/rsc-advances

\title{
Dehydration of fructose, sucrose and inulin to 5- hydroxymethylfurfural over yeast-derived carbonaceous microspheres at low temperatures $\uparrow$
}

\begin{abstract}
Xiaofeng Li, Yi Wang, Xiaomin Xie, Changhong Huang and Sen Yang (D)*
This work prepared carbonaceous microspheres by hydrothermal carbonization of yeast cells followed by sulfonation with concentrated sulphuric acid (98\%) at room temperature. The obtained carbonaceous product $\left(\mathrm{CM}-\mathrm{SO}_{3} \mathrm{H}\right)$ had a high acid density $\left(1.80 \mathrm{mmol} \mathrm{g}{ }^{-1}\right)$. We evaluated $\mathrm{CM}-\mathrm{SO}_{3} \mathrm{H}$ as a solid catalyst for the dehydration of fructose-based carbohydrates to 5-hydroxymethylfurfural (5-HMF) in the ionic liquid 1-butyl-3-methylimidazolium chloride ([BMIM][Cl]). The effects of the catalyst and substrate loadings as well as the reaction temperature and time on the yield of 5-HMF were investigated. Under the optimum conditions, a 5-HMF yield of up to $83.5 \%$ was obtained from fructose with a reaction temperature of $80{ }^{\circ} \mathrm{C}$ for $30 \mathrm{~min}$. Furthermore, 44.8\% and 59.2\% 5- HMF yields were obtained from sucrose $\left(80^{\circ} \mathrm{C}\right.$ for $\left.30 \mathrm{~min}\right)$ and inulin $\left(80{ }^{\circ} \mathrm{C}\right.$ for $\left.60 \mathrm{~min}\right)$, respectively. $\mathrm{CM}-\mathrm{SO} \mathrm{H}_{3} \mathrm{H}$ and [BMIM][Cl] showed high stability and could be recycled between five and eight times without significant loss of catalytic activity. More importantly, the catalytic system could be applied to high substrate concentrations. CM$\mathrm{SO}_{3} \mathrm{H}$ combined with [BMIM] [Cl] is a promising system for transforming fructose-based carbohydrates into 5-HMF.
\end{abstract}

\section{Introduction}

Biomass-derived chemicals have attracted interest for their potential to reduce global dependence upon fossil fuels. ${ }^{1}$ Among these chemicals, 5-hydroxylmethylfurfan (5-HMF) is one of the most important platform chemicals, and has been widely applied in the production of polymers, fine chemicals, pharmaceuticals, and biofuels. ${ }^{2,3} 5$-HMF can be generated from the dehydration of biomass derivatives such as fructose, ${ }^{4,5}$ glucose, ${ }^{6}$ sucrose $^{7}$ and cellulose. ${ }^{8}$ The most efficient method is dehydration of fructose catalysed by acid, ${ }^{9}$ as the conversion of other feedstocks requires a carbohydrate-to-fructose step. ${ }^{\mathbf{1 0}}$

Sulphuric acid ${ }^{\mathbf{1 1}}$ and hydrochloric acid ${ }^{\mathbf{1 2}}$ are efficient homogeneous catalysts for 5-HMF production through carbohydrate dehydration, but they have several drawbacks. These include difficulties with the separation and recycling of the catalyst, corrosion of equipment, and release of toxic waste. ${ }^{13}$ Heterogeneous catalysts can be used as an alternative to homogeneous catalysts to address these issues, and are more suitable for industrial applications. ${ }^{\mathbf{1 4 , 1 5}}$ Therefore, a variety of heterogeneous catalysts, such as solid superacids ${ }^{16}$ and acid cation

Beijing Key Laboratory of Farmland Soil Pollution Prevention and Remediation, College of Resources and Environmental Sciences, China Agricultural University, Beijing 100193, P. R. China. E-mail: syang@cau.edu.cn; Fax: +86-10-62733470; Tel: +86-10-62733470

$\dagger$ Electronic supplementary information (ESI) available. See DOI: 10.1039/c8ra10465d exchange resins, ${ }^{17,18}$ have been considered for the production of 5 -HMF. Functionalization of solid catalysts with $-\mathrm{SO}_{3} \mathrm{H}$ groups is an efficient and readily available means of improving the reaction rate and selectivity during the dehydration of carbohydrates to 5 -HMF. ${ }^{19}$

$\mathrm{SO}_{3} \mathrm{H}$-functionalized carbonaceous materials are very promising solid acid catalysts because they exhibit high stability and surface modifiability. ${ }^{\mathbf{2 0 2 1}}$ Recently, several carbonaceous materials, including mesoporous carbon, mesoporous carbonsilica composites, carbon nanotubes, biochar, and carbons prepared by the hydrothermal carbonization of biomass, have been modified with $-\mathrm{SO}_{3} \mathrm{H}$ groups and have shown good catalytic performance in the conversion of carbohydrates to 5HMF. ${ }^{1922,23}$ However, few studies have used hollow carbonaceous materials as catalysts for the conversion of carbohydrates to 5-HMF. Those carbonaceous materials that have been reported are commonly treated with concentrated sulphuric acid $(98 \%)$ at high temperatures to introduce $-\mathrm{SO}_{3} \mathrm{H}$ groups. As an example, biochar requires sulfonation at $150{ }^{\circ} \mathrm{C}$ for $12 \mathrm{~h},{ }^{2}$ and carbonized lignin $^{24}$ and cellulose-derived carbonaceous solids ${ }^{25}$ require sulfonation at $200{ }^{\circ} \mathrm{C}$ for $5-12 \mathrm{~h}$. The high temperatures required for the sulfonation process are a challenge because they result in harsh operational conditions and can cause equipment corrosion. ${ }^{22}$ However, any material that can be carbonized can be used to prepare $\mathrm{SO}_{3} \mathrm{H}$-functionalized carbonaceous materials. ${ }^{26}$ One such material is yeast produced as an organic waste by-product of the fermentation industry. The cell walls of yeast primarily consist of a polysaccharide layer 
constructed from coiled $\beta$-1,3-glucan chains, and hollow carbonaceous microspheres (CMs) with meso- and microporous shells have been prepared by the mild hydrothermal treatment of these organisms. ${ }^{27,28}$ Generally, hollow microspheres exhibit useful characteristics, such as improved mass transport and diffusion, high pile density and good fluidity, ${ }^{29,30}$ and so can be used as catalysts or catalyst supports. Most importantly, CMs are composed of both carbonized organic matter (that is, aromatic carbon) and non-carbonized organic matter (alkyl carbon), and the surfaces of these materials are covered with oxygenated functional groups, including carbonyl, carboxy, hydroxy, ether, and ester moieties. ${ }^{27,28}$ Therefore, it is easy to modify the surfaces of CMs by mild sulfonation. Even so, few studies have used CMs fabricated from yeast cells as precursors for solid acid catalysts.

The solvent is crucial in the production of 5-HMF from carbohydrates. $^{24}$ To date, water and highly polar organic solvents have been used as reaction solvents. ${ }^{14,31}$ However, the reaction temperatures are generally high $\left(120-180^{\circ} \mathrm{C}\right)$ and high energy inputs are required., ${ }^{77,25}$ As an example, the maximum 5HMF yield from the dehydration of fructose using sulfonated biochar as the catalyst and water as the solvent is obtained at 160-180 ${ }^{\circ} \mathrm{C} .{ }^{4}$ With DMSO as the solvent, the transformation of fructose into 5 -HMF is generally performed at $120{ }^{\circ} \mathrm{C} .{ }^{9}$ Ionic liquids (ILs) are organic salts that are liquids at room temperature and can be easily recycled. ${ }^{32,33}$ According to the literature, ILs such as [HMIM] [Cl], [OMIM][Cl], and [BEMIM][Cl] can play a positive role in the dehydration of carbohydrates because of their good solvating powers. ${ }^{\mathbf{4 , 2 1 , 2 2 , 3 4}}$ The dehydration of fructose in ILs can give a high 5-HMF yield at temperatures as low as $80{ }^{\circ} \mathrm{C}^{35}$ Among the ILs, 1-butyl-3-methylimidazolium chloride ([BMIM] $][\mathrm{Cl}]$ ) is a suitable medium for the production of 5-HMF from fructose since it can act as both a proton donor and acceptor. $^{24,36}$

In this work, we prepared CMs via the hydrothermal treatment of yeast cells, as reported previously. ${ }^{27} \mathrm{SO}_{3} \mathrm{H}$ functionalized microspheres were subsequently obtained after immersion of these CMs in concentrated sulphuric acid (98\%) at room temperature. The catalytic activities of the resulting catalysts were estimated during the production of 5-HMF from fructose, sucrose, and inulin.

\section{Experimental}

\section{Materials and reagents}

Budding yeast (Saccharomyces cerevisiae) was purchased from the Angel Yeast Co., Ltd. (Yichang, China). Fructose (99\%) and sucrose (99\%) were purchased from the Sigma-Aldrich Co., Ltd. (Missouri, USA). Inulin (90\%) was purchased from the Yuan Ye Biotechnology Co., Ltd. (Shanghai, China) and 5-HMF (99\%) was purchased from the Aladdin Chemicals Co., Ltd. (California, USA). Acetone (99\%), ethyl alcohol (99\%), ethyl acetate (99\%), and concentrated sulphuric acid (98\%) were obtained from the Sinopharm Chemical Reagent Co., Ltd. (Shanghai, China). Methanol (HPLC grade) was purchased from the Fisher Chemicals Co., Ltd. (New Jersey, USA). [BMIM][Cl] (99\%) was purchased from the Linzhou Keneng Materials Technology Co.,
Ltd. (Linzhou, China). Ultrapure water was used in all experiments. All chemicals were used as obtained without further treatment.

\section{Preparation of the catalyst}

CMs were synthesized by a modification of the hydrothermal method described in our previous study. ${ }^{27}$ Typically, $S$. cerevisiae cells (3.0-4.0 g) were pre-washed with acetone and then dispersed in ultrapure water $(40 \mathrm{~mL})$. The mixture was subsequently placed in a $50 \mathrm{~mL}$ Teflon-sealed autoclave and maintained at $180{ }^{\circ} \mathrm{C}$ for $8 \mathrm{~h}$. The puce-colored solid product was isolated by centrifugation, washed alternately with ultrapure water and ethyl alcohol three times, and oven-dried at $80{ }^{\circ} \mathrm{C}$ for $8 \mathrm{~h}$. This material is referred to herein as the CMs.

The CMs $(1.0 \mathrm{~g})$ were then dispersed in concentrated sulphuric acid $(20 \mathrm{~mL})$ at room temperature with stirring at $800 \mathrm{rpm}$. After a certain time, the resulting black precipitate was removed by filtration and washed with water until the wash water was neutral. The sulfonated material obtained in this manner was dried at $75{ }^{\circ} \mathrm{C}$ in a vacuum oven overnight. The CMs sulfonated for $8 \mathrm{~h}$ are denoted herein as $\mathrm{CM}-\mathrm{SO}_{3} \mathrm{H}$.

\section{Characterization}

Field-emission scanning electron microscopy (FE-SEM, SU 8020, Hitachi, Japan) was used to obtain images of the CMs and $\mathrm{CM}-\mathrm{SO}_{3} \mathrm{H}$. Fourier-transform infrared (FTIR) spectra were acquired over the range of $400-4000 \mathrm{~cm}^{-1}$ (IS 10, Nicolet, USA) and the $\mathrm{C}, \mathrm{H}, \mathrm{N}, \mathrm{O}$, and $\mathrm{S}$ contents of the samples were determined using an elemental analyser (Flash 2000, Therom, USA). The surface areas and pore sizes of the CMs and $\mathrm{CM}-\mathrm{SO}_{3} \mathrm{H}$ were obtained from $\mathrm{N}_{2}$ adsorption/desorption isotherms acquired at $-196.15{ }^{\circ} \mathrm{C}$ with a physisorption analyser (ASAP 2020, Micromeritics, USA). The total number of acid sites in the $\mathrm{CM}-\mathrm{SO}_{3} \mathrm{H}$ was estimated by acid-base titration. ${ }^{5,9}$ Briefly, $\mathrm{CM}^{-\mathrm{SO}_{3} \mathrm{H}}(0.10$ g) was suspended in $50 \mathrm{~mL}$ of aqueous $0.5 \mathrm{M} \mathrm{NaCl}$ and stirred for $24 \mathrm{~h}$. During this time, $\mathrm{H}^{+}$was liberated into the aqueous solution by exchange with $\mathrm{Na}^{+}$. The filtrate was subsequently titrated using a standard $\mathrm{NaOH}$ solution $(0.01 \mathrm{M})$.

\section{Catalytic dehydration of carbohydrates to 5-HMF}

The dehydration reactions of carbohydrates were performed in $10 \mathrm{~mL}$ glass tubes. Typically, a feedstock $(0.50 \mathrm{~g}$ of fructose, $0.25 \mathrm{~g}$ of sucrose, or $0.25 \mathrm{~g}$ of inulin) was dissolved in $2.50 \mathrm{~g}$ of $[\mathrm{BMIM}][\mathrm{Cl}]$ at $60{ }^{\circ} \mathrm{C}$, after which $50 \mathrm{mg}$ of $\mathrm{CM}-\mathrm{SO}_{3} \mathrm{H}$ was added rapidly with stirring at $800 \mathrm{rpm}$. The reactor was then heated to $80{ }^{\circ} \mathrm{C}$ in an oil bath. After the desired reaction time had elapsed, the products were extracted into ethyl acetate with stirring at room temperature.

In an experiment to test the reusability of the catalyst, the 5HMF produced after 30 min of reaction was extracted by $25 \mathrm{~mL}$ ethyl acetate. After four such extractions, the remaining [BMIM] [Cl] and $\mathrm{CM}-\mathrm{SO}_{3} \mathrm{H}$ were heated at $80{ }^{\circ} \mathrm{C}$ for $12 \mathrm{~h}$ in a vacuum drying oven to remove water and residual ethyl acetate. The residue was used directly for the next carbohydrate to 5-HMF conversion with fresh feedstock. 


\section{Analytical methods}

The ${ }^{1} \mathrm{H}$ nuclear magnetic resonance (NMR) spectrum of 5-HMF was recorded in $d_{4}$-methanol at $25{ }^{\circ} \mathrm{C}$ using a $400 \mathrm{MHz}$ NMR spectrometer (JNM-ECZ, Jeol, Japan). The amount of 5-HMF obtained from each reaction was analysed directly by HPLC with a Zorbax SB-C18 column $(4.6 \mathrm{~mm} \times 12.5 \mathrm{~mm})$ and methanol/ water $(20: 80, \mathrm{v} / \mathrm{v})$ as the mobile phase. ${ }^{37}$ The flow rate was 0.7 $\mathrm{mL} \min ^{-1}$ and the column temperature was kept at $30{ }^{\circ} \mathrm{C}$. The carbohydrate content was determined by HPLC with an Aminex HPX-87H column $(300 \mathrm{~mm} \times 7.8 \mathrm{~mm})$ in conjunction with a refractive index detector. The mobile phase was $5 \mathrm{mM} \mathrm{H}_{2} \mathrm{SO}_{4}$ at a flow rate of $1.0 \mathrm{~mL} \mathrm{~min} \mathrm{~m}^{-1}$ and the column temperature was maintained at $55{ }^{\circ} \mathrm{C} .{ }^{38,39}$ The 5 -HMF yield and carbohydrate conversion were calculated using the following equations.

$$
\begin{aligned}
& 5 \text {-HMF yield }(\%)=\frac{5 \text {-HMF produced }(\mathrm{mol})}{\text { initial carbohydrate }(\mathrm{mol})} \times 100 \% \\
& \text { Conversion }(\%)=\frac{\text { carbohydrate consumed }(\mathrm{g})}{\text { initial carbohydrate }(\mathrm{g})} \times 100 \%
\end{aligned}
$$

Each experiment was repeated at least three times with similar results, and all the reported reaction data are averages.

\section{Results and discussion}

\section{Catalyst screening}

We prepared all solid acid catalysts under the same conditions, except that the sulfonation time was varied from 0 to $8 \mathrm{~h}$. The hydrothermal carbonization was carried out at $180^{\circ} \mathrm{C}$ for $8 \mathrm{~h}$ and the sulfonation was conducted at room temperature in concentrated sulphuric acid. The catalytic activities of the samples were investigated based on the dehydration of fructose, which was found to be the most reactive substrate (Fig. 1).

We carried out a preliminary experiment in the absence of a catalyst in [BMIM] [Cl] at $80{ }^{\circ} \mathrm{C}$ for $30 \mathrm{~min}$, but no $5-\mathrm{HMF}$ was obtained. It should be noted that, at $120^{\circ} \mathrm{C},[\mathrm{BMIM}][\mathrm{Cl}]$ can act as both solvent and catalyst during fructose dehydration. ${ }^{24}$ This

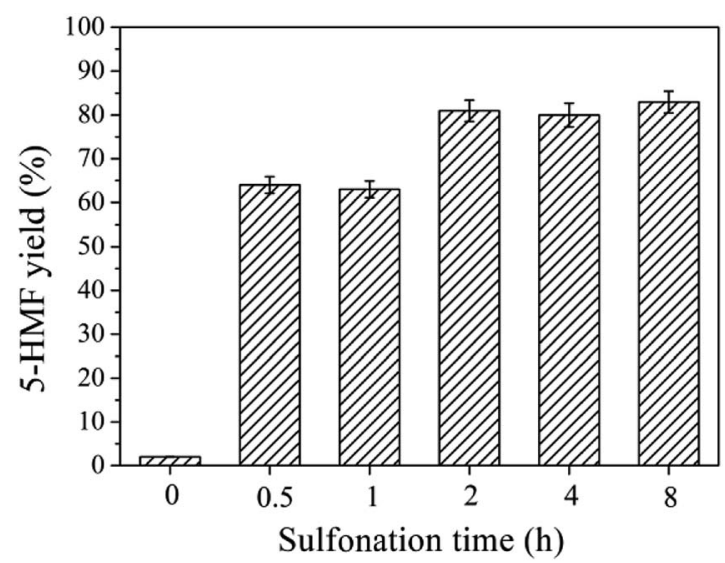

Fig. 1 The effect of sulfonation time on the 5-HMF yield from fructose. Reaction conditions: fructose $(0.50 \mathrm{~g})$, catalyst $(50 \mathrm{mg})$, [BMIM] [Cl] $(2.50 \mathrm{~g})$, reaction temperature $\left(80^{\circ} \mathrm{C}\right)$, and reaction time (30 $\left.\mathrm{min}\right)$. indicates that the catalytic activity of [BMIM] $[\mathrm{Cl}]$ is dependent on the reaction temperature. ${ }^{34}$ However, at $80{ }^{\circ} \mathrm{C}$, the catalytic activity of the [BMIM][Cl] was negligible. Adding $50 \mathrm{mg}$ of CMs gave a 5 -HMF yield of approximately $2.1 \%$, and so it was clear that the CMs exhibited little catalytic activity under the present conditions. However, a large increase in the catalytic activity occurred after the CMs were sulfonated. The yield of 5-HMF increased to $64.0 \%$ with the addition of $\mathrm{CMs}$ that were sulfonated for $0.5 \mathrm{~h}$, suggesting that $-\mathrm{SO}_{3} \mathrm{H}$ groups served as active sites on the catalyst. ${ }^{9}$ A higher 5 -HMF yield of $81.0 \%$ was obtained when the sulfonation time was increased to $2 \mathrm{~h}$, and a slight further increase in the yield was observed following an additional increase in sulfonation time to $8 \mathrm{~h} .{ }^{1} \mathrm{H}$ NMR spectroscopy (Fig. S1 $\dagger$ ) confirmed the production of 5-HMF. These results show that the sulfonation of CMs at room temperature is an effective approach to preparing highly active catalysts for the synthesis of 5-HMF from fructose. Furthermore, the sulfonation time has a remarkable effect on the catalytic activity of the CMs. We selected the CMs sulfonated for $8 \mathrm{~h}\left(\mathrm{CM}-\mathrm{SO}_{3} \mathrm{H}\right)$ as the most active and stable catalyst for all the following experiments.

The catalytic activity of the $\mathrm{CM}-\mathrm{SO}_{3} \mathrm{H}$ during the dehydration of glucose, the least reactive substrate, was also assessed..$^{40} \mathrm{~A}$ 5HMF yield of $10.2 \%$ was obtained at $120^{\circ} \mathrm{C}$ after $2 \mathrm{~h}$. The low 5$\mathrm{HMF}$ yield from glucose may be explained by the lack of Lewis acid sites on $\mathrm{CM}-\mathrm{SO}_{3} \mathrm{H}$, because 5-HMF synthesis from glucose involves isomerization catalysed by a Lewis acid and dehydration catalysed by a Brønsted acid. ${ }^{41}$

\section{Characterization of the $\mathrm{CM}-\mathrm{SO}_{3} \mathrm{H}$ catalyst}

SEM images of the CMs and $\mathrm{CM}-\mathrm{SO}_{3} \mathrm{H}$ are presented in Fig. 2. The obtained CMs were in the form of microspheres with diameters in the $2.0-3.0 \mu \mathrm{m}$ range, which was consistent with our previous results. ${ }^{27}$ After sulfonation, the microsphere structure was well preserved but the diameter decreased to 1.0$2.0 \mu \mathrm{m}$. The surface area of the $\mathrm{CM}-\mathrm{SO}_{3} \mathrm{H}$ was $12.5 \mathrm{~m}^{2} \mathrm{~g}^{-1}$, which was slightly higher than that of the CMs $\left(10.5 \mathrm{~m}^{2} \mathrm{~g}^{-1}\right)$ (Table 1). The CMs pore size was $15.5 \mathrm{~nm}$, whereas that of the $\mathrm{CM}-\mathrm{SO}_{3} \mathrm{H}$ was $16.6 \mathrm{~nm}$. From these results, it was clear that the CMs were etched by the concentrated sulphuric acid.

Fig. 3 shows the FTIR spectra of the CMs and $\mathrm{CM}-\mathrm{SO}_{3} \mathrm{H}$. A new band appearing at $1169 \mathrm{~cm}^{-1}$ in the FTIR spectrum of the $\mathrm{CM}-\mathrm{SO}_{3} \mathrm{H}$ was ascribed to the $\mathrm{O}=\mathrm{S}=\mathrm{O}$ stretching vibration of $-\mathrm{SO}_{3} \mathrm{H}$ groups, ${ }^{42}$ and this confirmed that $-\mathrm{SO}_{3} \mathrm{H}$ groups were successfully incorporated into the CMs during the sulfonation process. ${ }^{38,43,44}$ The band at $3431 \mathrm{~cm}^{-1}$ indicated the presence of
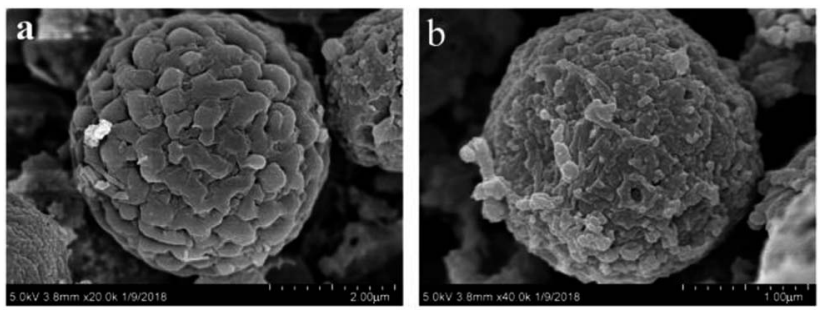

Fig. 2 SEM images of $\mathrm{CMs}(\mathrm{a})$ and $\mathrm{CM}-\mathrm{SO}_{3} \mathrm{H}(\mathrm{b})$. 
Table 1 Acid density (AD), BET surface area (SA), pore size $(W)$, elemental composition, and atomic ratio data for the $\mathrm{CMs}$ and $\mathrm{CM}^{-} \mathrm{SO} \mathrm{H}^{a}$

\begin{tabular}{|c|c|c|c|c|c|c|c|c|c|c|}
\hline Sample & $\mathrm{AD}\left(\mathrm{mmol} \mathrm{g}^{-1}\right)$ & $\mathrm{SA}\left(\mathrm{m}^{2} \mathrm{~g}^{-1}\right)$ & $W(\mathrm{~nm})$ & \multicolumn{5}{|c|}{ Elemental compositions (wt\%) } & \multicolumn{2}{|c|}{ Atomic ratio } \\
\hline $\mathrm{CM}-\mathrm{SO}_{3} \mathrm{H}$ & 1.80 & 12.5 & 16.6 & 56.27 & 5.76 & 28.33 & 4.62 & 4.02 & 0.38 & 0.45 \\
\hline
\end{tabular}

${ }^{a} \mathrm{O} / \mathrm{C}$ : atomic ratio of oxygen to carbon. $(\mathrm{O}+\mathrm{N}) / \mathrm{C}$ : atomic ratio of the sum of nitrogen and oxygen to carbon.

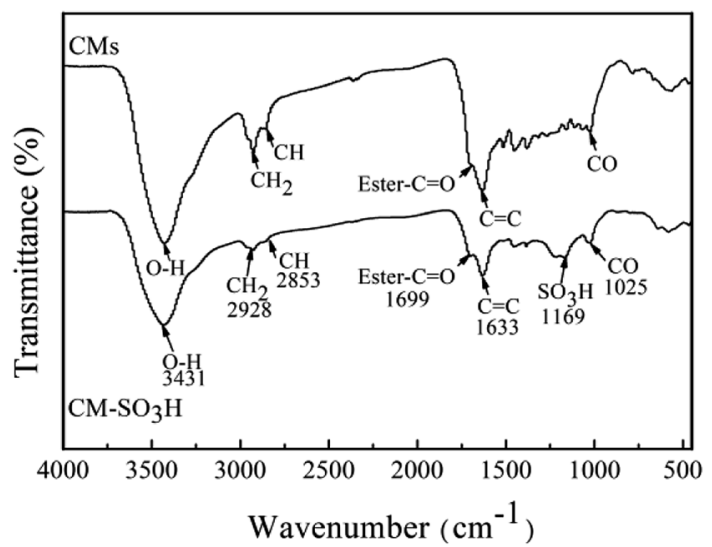

Fig. 3 FTIR spectra of the $\mathrm{CMs}$ and $\mathrm{CM}-\mathrm{SO}_{3} \mathrm{H}$.

$-\mathrm{OH}$ groups ${ }^{22,44}$ on the surfaces of both the $\mathrm{CMs}$ and $\mathrm{CM}-\mathrm{SO}_{3} \mathrm{H}$. Bands at 2928 and $2853 \mathrm{~cm}^{-1}$ were attributed to $-\mathrm{CH}_{2}$ and $-\mathrm{CH}$ stretching vibrations, ${ }^{19,27}$ and the intensities of these bands decreased dramatically after sulfonation of the CMs, indicating that these surface functional groups were removed. This could have been caused by the sulphuric acid, which is a strong oxidizer.

The elemental compositions of the CMs and $\mathrm{CM}-\mathrm{SO}_{3} \mathrm{H}$ are shown in Table 1. These results are in good agreement with the FTIR spectra. Following sulfonation, the sulphur percentage greatly increased, from $0.20 \%$ in the CMs to $4.02 \%$ in the CM$\mathrm{SO}_{3} \mathrm{H}$, which also confirmed the existence of $-\mathrm{SO}_{3} \mathrm{H}$ groups in the $\mathrm{CM}-\mathrm{SO}_{3} \mathrm{H}^{45}$ In addition, the $\mathrm{C}$ and $\mathrm{O}$ contents of the CMs were decreased after sulfonation. The polarity index, $[(\mathrm{O}+\mathrm{N}) / \mathrm{C}]$, of the $\mathrm{CM}-\mathrm{SO}_{3} \mathrm{H}$ increased, confirming an increase in the number of polar functional groups on the surface. ${ }^{27}$

Because the acid strength of a solid catalyst is a key parameter for the dehydration of carbohydrates, ${ }^{19,46}$ we characterized the acidities of the samples by titration. ${ }^{5}$ The acid density was also greatly increased, from $0.20 \mathrm{mmol} \mathrm{g}^{-1}$ for the CMs to $1.80 \mathrm{mmol} \mathrm{g}^{-1}$ for $\mathrm{CM}-\mathrm{SO}_{3} \mathrm{H}$ (Table 1). Therefore, it is clear that the enhanced catalytic activity of the $\mathrm{CM}-\mathrm{SO}_{3} \mathrm{H}$ may be attributed to its high acid density.

The results from our preliminary experiment inspired us to investigate the synthesis of 5-HMF from fructose and fructosebased carbohydrates (fructose, sucrose, and inulin) over the $\mathrm{CM}-\mathrm{SO}_{3} \mathrm{H}$ catalyst in $[\mathrm{BMIM}][\mathrm{Cl}]$.

\section{Effect of the reaction temperature and time on 5-HMF yields}

We explored the effects of the reaction temperature and time on the fructose, sucrose, and inulin dehydrations catalysed by CM$\mathrm{SO}_{3} \mathrm{H}$ in [BMIM][Cl] (Fig. 4). All experiments were carried out with $50 \mathrm{mg}$ of $\mathrm{CM}-\mathrm{SO}_{3} \mathrm{H}$ and $2.50 \mathrm{~g}$ of [BMIM][Cl]. The masses of fructose, sucrose, and inulin were $0.50 \mathrm{~g}, 0.25 \mathrm{~g}$ and $0.25 \mathrm{~g}$, respectively. The reaction temperature played an important role in determining the 5-HMF yield. When the conversion of fructose was carried out at $70{ }^{\circ} \mathrm{C}$, the 5 -HMF yield increased to a maximum of $80.7 \%$ at $60 \mathrm{~min}$ and then reached a plateau. When the reaction temperature was increased to 80 or $90^{\circ} \mathrm{C}$, the reaction rate increased in the initial stages of the reaction. The maximum 5-HMF yields were obtained at $30 \mathrm{~min}(83.5 \%)$ and $20 \mathrm{~min}(75.6 \%)$ with reaction temperatures of $80^{\circ} \mathrm{C}$ and $90{ }^{\circ} \mathrm{C}$, respectively. The 5-HMF yields then decreased slightly with further increases in the reaction time at $80{ }^{\circ} \mathrm{C}$ and $90{ }^{\circ} \mathrm{C}$.
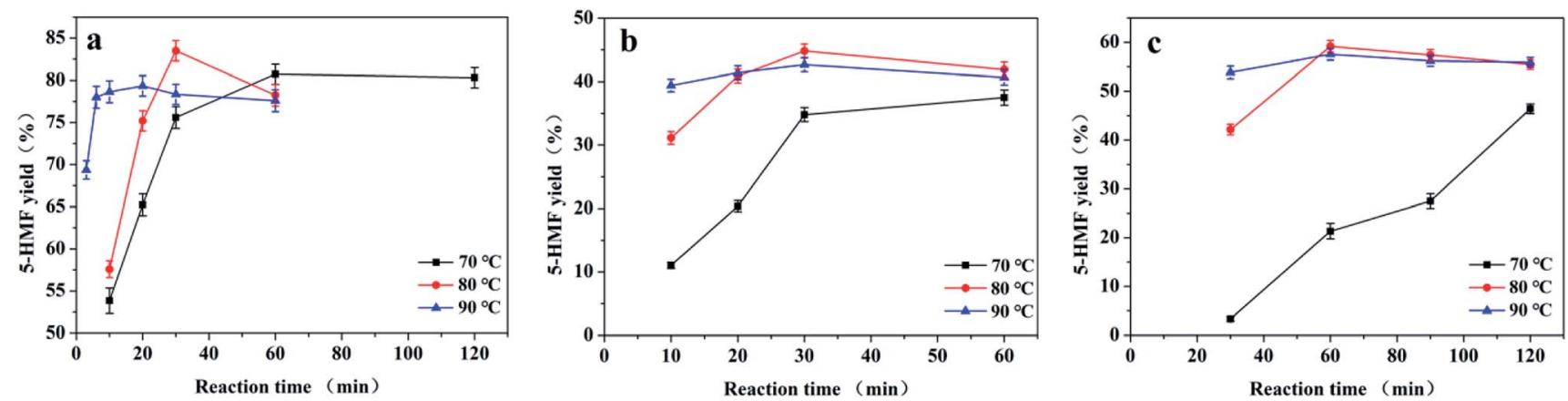

Fig. 4 Effect of the reaction temperature on the yield of 5-HMF from fructose (a), sucrose (b), and inulin (c). Reaction conditions: catalyst (50 $\mathrm{mg})$, [BMIM][Cl] $(2.50 \mathrm{~g})$, fructose $(0.50 \mathrm{~g})$, sucrose $(0.25 \mathrm{~g})$, and inulin $(0.25 \mathrm{~g})$. 

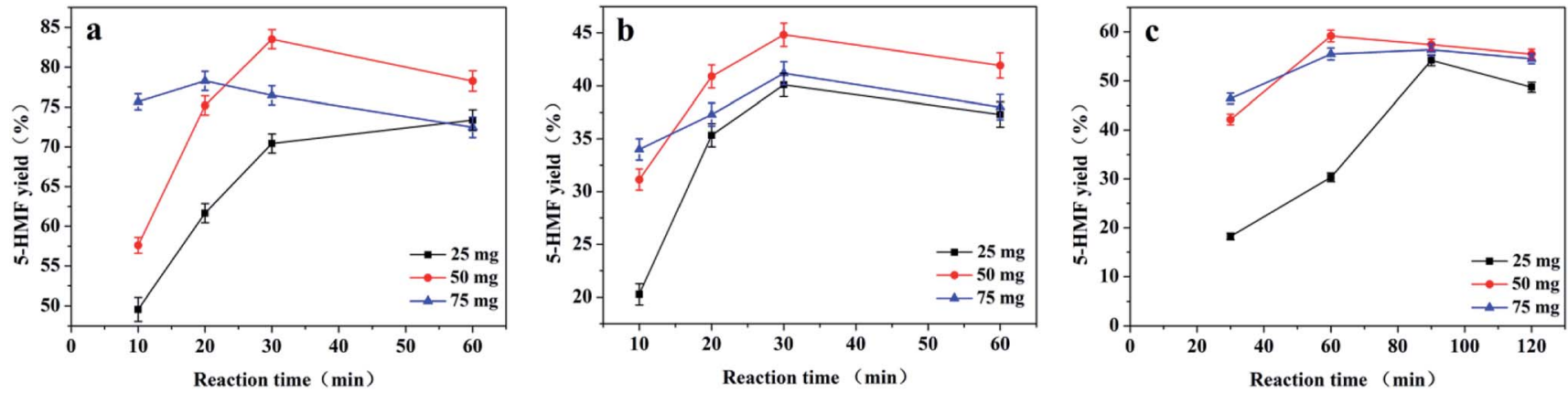

Fig. 5 Effect of catalyst loading on the yield of 5-HMF from fructose (a), sucrose (b), and inulin (c). Reaction conditions: [BMIM][Cl] (2.50 g), fructose $(0.50 \mathrm{~g})$, sucrose $(0.25 \mathrm{~g})$, inulin $(0.25 \mathrm{~g})$, and reaction temperature $\left(80^{\circ} \mathrm{C}\right)$.

The same tendency was observed for sucrose and inulin dehydration. At $70^{\circ} \mathrm{C}$, the 5-HMF yields were low and increased continuously with the reaction time. In contrast, at higher temperatures (80 and $90{ }^{\circ} \mathrm{C}$ ), the 5-HMF yields initially increased with the reaction time and then slightly decreased with further increases in the reaction time. The maximum 5HMF yields from sucrose and inulin were $44.8 \%\left(80^{\circ} \mathrm{C}, 30 \mathrm{~min}\right)$ and $59.2 \%\left(80^{\circ} \mathrm{C}, 60 \mathrm{~min}\right)$, respectively.

The decrease in the 5-HMF yield at higher temperatures suggests that the 5-HMF was consumed by humins. ${ }^{13,44}$ The formation of humins is inevitable in the acid-catalysed dehydration of carbohydrates because water is produced, and the generation of humins can be simply determined by the observation of a brown colour in the reaction mixture. ${ }^{22,38}$ To support this, we indirectly observed the colour of the reaction mixture by assessing the ethyl acetate extract (Fig. S2 $\dagger$ ). Direct observation of the reaction mixture was not possible because the catalyst was black and obscured the colour of the solution. The ethyl acetate extract of the reaction mixture for the reaction at $70{ }^{\circ} \mathrm{C}$ for 5 min was colourless. However, when the reaction temperature was increased to 80 or $90{ }^{\circ} \mathrm{C}$, the solution turned very pale yellow or light yellow, respectively. As the reaction time increased, the extract became darker (Fig. S2b †).

These results show that higher reaction temperatures both improve the conversion of fructose to 5-HMF and accelerate the formation of humins and therefore the consumption of 5HMF. ${ }^{22,44}$ Thus, an appropriate temperature $\left(80^{\circ} \mathrm{C}\right)$ and time
(30 min for fructose and sucrose, and 60 min for inulin) are required to achieve the maximum 5-HMF yield.

\section{Effect of catalyst and substrate loadings on the 5-HMF yield}

The effect of catalyst loading (25-75 mg) together with that of the reaction time was evaluated at $80^{\circ} \mathrm{C}$ in $2.50 \mathrm{~g}$ of [BMIM] [Cl]. The masses of fructose, sucrose, and inulin were $0.50 \mathrm{~g}, 0.25 \mathrm{~g}$, and $0.25 \mathrm{~g}$, respectively. A higher 5-HMF yield was obtained from each of the substrates in a shorter reaction time when the mass of catalyst was increased from 25 to $50 \mathrm{mg}$ (Fig. 5). As an example, the yields of 5-HMF from fructose and sucrose steadily increased from $49.6 \%$ to $57.6 \%$ and from $20.2 \%$ to $31.1 \%$ after $10 \mathrm{~min}$, respectively. In the case of inulin, the 5-HMF yield steadily increased from $18.2 \%$ to $42.2 \%$ after $30 \mathrm{~min}$. The increase in the 5-HMF yield with increases in the catalyst loading may be attributed to an increase in the number of active sites and their availability. ${ }^{19,47}$ However, the maximum yields of 5-HMF from the three substrates were obtained with a catalyst loading of $50 \mathrm{mg}$, while the 5-HMF yield decreased when the catalyst loading was increased to $75 \mathrm{mg}$. These results suggest that degradation of the 5-HMF is also catalysed by active acid sites. ${ }^{19,48}$

High substrate loadings are essential to improving the economy of 5 -HMF production. ${ }^{17}$ We investigated the effect of the initial substrate concentration on the production of 5-HMF in reactions catalysed by $\mathrm{CM}_{-} \mathrm{SO}_{3} \mathrm{H}$ in $[\mathrm{BMIM}][\mathrm{Cl}]$ (Fig. 6). The 5-
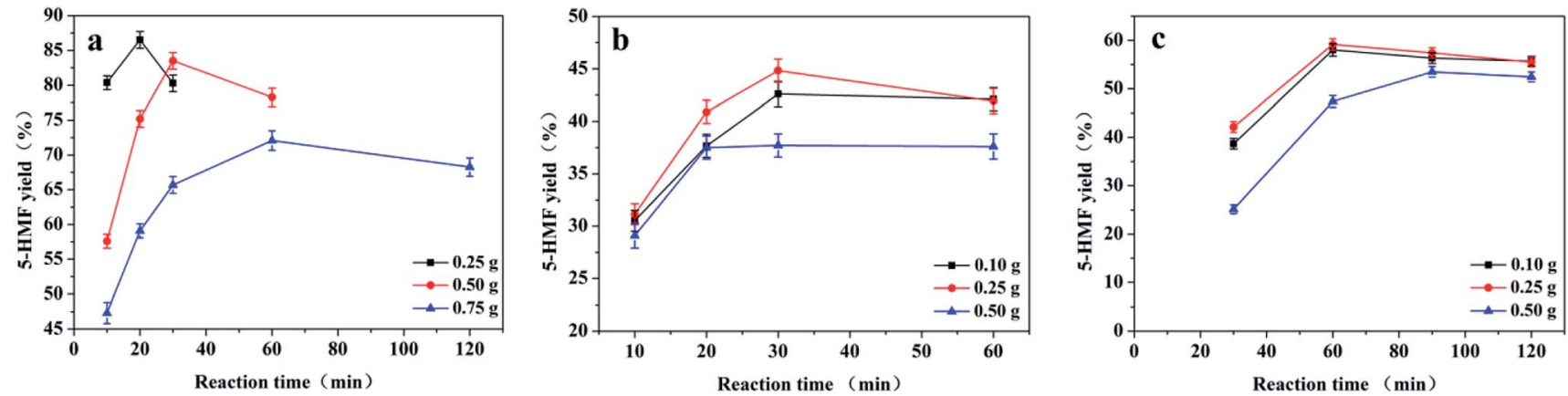

Fig. 6 Effect of the substrate loading on the yield of 5-HMF from fructose (a), sucrose (b), and inulin (c). Reaction conditions: catalyst (50 mg), $[\mathrm{BMIM}][\mathrm{Cl}](2.50 \mathrm{~g})$, and reaction temperature $\left(80^{\circ} \mathrm{C}\right)$. 
Table 2 Overview of carbohydrate conversion to 5-HMF in different ionic liquids ${ }^{a}$

\begin{tabular}{|c|c|c|c|c|c|c|c|c|}
\hline Car. & Catalyst & Ionic liquid & $C_{\text {car. }}(\mathrm{wt} \%)$ & $T\left({ }^{\circ} \mathrm{C}\right)$ & $\begin{array}{l}t \\
(\min )\end{array}$ & $\begin{array}{l}\text { Yield } \\
(\%)\end{array}$ & Con. (\%) & Ref. \\
\hline Fructose & $\mathrm{CM}-\mathrm{SO}_{3} \mathrm{H}$ & [BMIM][Cl] & 20 & 80 & 30 & 83.5 & 98.1 & - \\
\hline Fructose & SBA-15- $\mathrm{SO}_{3} \mathrm{H}$ & {$[\mathrm{BMIM}][\mathrm{Cl}]$} & 10 & 120 & 60 & $\sim 81$ & $\sim 100$ & 24 \\
\hline Fructose & LCC & {$[\mathrm{BMIM}][\mathrm{Cl}] / \mathrm{DMSO}$} & 10 & 110 & 10 & 84 & 98 & 38 \\
\hline Fructose & HTC & {$[\mathrm{BMIM}][\mathrm{Cl}]$} & 1 & 100 & 90 & 88.1 & n.m. & 22 \\
\hline Sucrose & $\mathrm{CM}-\mathrm{SO}_{3} \mathrm{H}$ & {$[\mathrm{BMIM}][\mathrm{Cl}]$} & 10 & 80 & 30 & 44.8 & 99.9 & - \\
\hline Sucrose & $\mathrm{H}_{3} \mathrm{BO}_{3}-\mathrm{SiO}_{2}$ & {$[\mathrm{BMIM}]\left[\mathrm{HSO}_{4}\right]$} & 10 & 120 & 180 & 80 & n.m. & 50 \\
\hline Inulin & $\mathrm{CM}-\mathrm{SO}_{3} \mathrm{H}$ & [BMIM $][\mathrm{Cl}]$ & 10 & 80 & 60 & 59.2 & 99.6 & - \\
\hline Inulin & $\mathrm{H}_{3} \mathrm{BO}_{3}-\mathrm{SiO}_{2}$ & {$[\mathrm{BMIM}]\left[\mathrm{HSO}_{4}\right]$} & 10 & 120 & 300 & 88 & n.m. & 50 \\
\hline Inulin & $\mathrm{D} 265-\mathrm{SO}_{3} \mathrm{H}$ & {$[\mathrm{AMIM}][\mathrm{Cl}]$} & 5 & 100 & 60 & 65 & n.m. & 52 \\
\hline Inulin & Amberlyst-15 & {$[\mathrm{BMIM}]\left[\mathrm{HSO}_{4}\right] /[\mathrm{BMIM}][\mathrm{Cl}]$} & 2.5 & 80 & 65 & 82 & n.m. & 53 \\
\hline
\end{tabular}

${ }^{a} C_{\text {car }}=$ concentration of carbohydrate, $T=$ reaction temperature $\left({ }^{\circ} \mathrm{C}\right), t=$ reaction time $(\mathrm{min}), \mathrm{n} . \mathrm{m} .=$ not mentioned, Car. $=$ carbohydrate, Con. $=$ conversion, Ref. $=$ reference.

HMF yield decreased gradually as the fructose mass increased in the initial stages of the reaction. The highest 5-HMF yields were $86.5 \%, 83.5 \%$, and $72.1 \%$ with $0.25,0.50$, and $0.75 \mathrm{~g}$ of fructose, respectively. With sucrose and inulin, the 5-HMF yields increased slightly as the mass of substrate was increased from 0.10 to $0.25 \mathrm{~g}$. However, a further increase in the substrate mass to $0.50 \mathrm{~g}$ led to a decreased 5-HMF yield. The highest 5HMF yields were $42.6 \%, 44.8 \%$, and $37.7 \%$ with $0.10,0.25$, and $0.50 \mathrm{~g}$ of sucrose, respectively. Using $0.10,0.25$, and $0.50 \mathrm{~g}$ of inulin, the highest 5-HMF yields were $58.0 \%, 59.2 \%$, and $53.5 \%$, respectively.

We compared the data for our catalyst with representative literature data regarding 5-HMF production from various heterogeneous catalysts in ILs (Table 2). CM- $\mathrm{SO}_{3} \mathrm{H}$ compares favourably with other solid catalysts in terms of the substrate concentration and reaction temperature when $[\mathrm{BMIM}][\mathrm{Cl}]$ is used as the reaction solvent.

\section{Catalyst recycling}

Stability is a key factor for practical applications of solid catalysts. To investigate the reusability of $\mathrm{CM}-\mathrm{SO}_{3} \mathrm{H}$ in the
carbohydrate-[BMIM][Cl] reaction system, we conducted recycling experiments at $80{ }^{\circ} \mathrm{C}$ according to an established method. ${ }^{44,49}$ After each reaction, the 5-HMF was recovered from the reaction mixture by extraction into ethyl acetate $(4 \times 25$ $\mathrm{mL})$. Subsequently, the $[\mathrm{BMIM}][\mathrm{Cl}]$ that contained the $\mathrm{CM}-\mathrm{SO}_{3} \mathrm{H}$ was dried in a vacuum oven at $80^{\circ} \mathrm{C}$ for $12 \mathrm{~h}$ and reused directly in the next reaction under the same conditions.

The yield of 5-HMF from fructose was almost unchanged after eight cycles of the reaction with [BMIM] [Cl] and the catalyst (Fig. 7). The recycled catalyst and [BMIM][Cl] were evidently stable during the conversion of fructose to $5-\mathrm{HMF}$, indicating that the $-\mathrm{SO}_{3} \mathrm{H}$ groups were tightly bonded to the $\mathrm{CM}-\mathrm{SO}_{3} \mathrm{H}$. The yields of 5-HMF from sucrose and inulin decreased slightly, from $44.8 \%$ to $31.0 \%$ and from $59.2 \%$ to $46.9 \%$, respectively, after five successive cycles of catalyst reuse. This slight decrease in yield is possibly attributable to the generation of glucose during the hydration of sucrose and inulin (based on HPLC results that are not included herein). This glucose was not removed from the reaction system and thus could have combined with the 5-HMF to promote polymerization to form humins which, in turn, would lower the HMF yield. Moreover, some portion of the humins likely deposited on the catalyst and
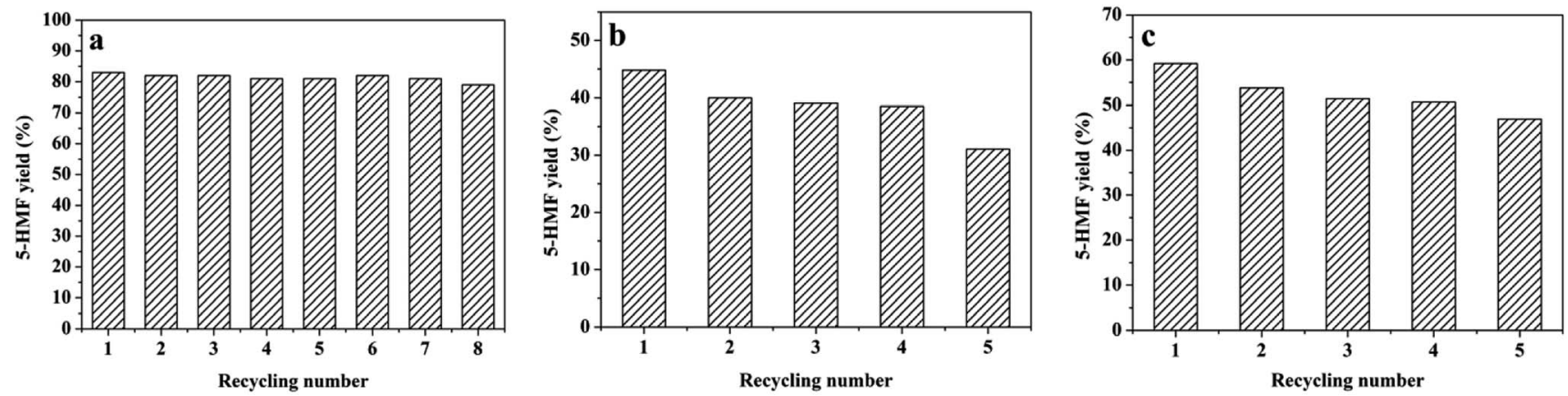

Fig. 7 Reusability of $\mathrm{CM}-\mathrm{SO}_{3} \mathrm{H}$ for fructose (a), sucrose (b), and inulin (c) conversion to 5-HMF. Reaction conditions: fructose (0.50 g), sucrose $(0.25 \mathrm{~g})$, or inulin $(0.25 \mathrm{~g}) ; \mathrm{CM}-\mathrm{SO}_{3} \mathrm{H}(50 \mathrm{mg})$; [BMIM] [Cl] $(2.50 \mathrm{~g})$; temperature $\left(80{ }^{\circ} \mathrm{C}\right)$; and reaction time $(30 \mathrm{~min})$. 
reduced the catalytic activity of the $\mathrm{CM}-\mathrm{SO}_{3} \mathrm{H} \cdot{ }^{13,38}$ As shown in Fig. S3, $\uparrow$ after five cycles of the sucrose dehydration reaction, humins or other organic residues were deposited on the surface of the $\mathrm{CM}-\mathrm{SO}_{3} \mathrm{H}$, even after washing alternately with hot water and ethanol three times.

\section{Conclusions}

We prepared $\mathrm{SO}_{3} \mathrm{H}$-functionalized $\mathrm{CMs}\left(\mathrm{CM}-\mathrm{SO}_{3} \mathrm{H}\right)$ by the hydrothermal carbonization of yeast cells, followed by sulfonation at room temperature. We applied the $\mathrm{CM}-\mathrm{SO}_{3} \mathrm{H}$ to the synthesis of 5-HMF from fructose-based carbohydrates in

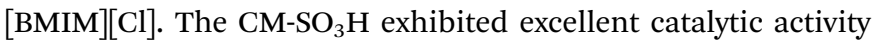
during the conversions of fructose, sucrose, and inulin to 5HMF at low reaction temperatures and high substrate concentrations. When $0.50 \mathrm{~g}$ of fructose was used, a high 5-HMF yield of $83.5 \%$ was obtained in $2.50 \mathrm{~g}$ of [BMIM][Cl] after reaction at $80{ }^{\circ} \mathrm{C}$ for $30 \mathrm{~min}$. With $0.25 \mathrm{~g}$ of sucrose $\left(30 \mathrm{~min}\right.$ at $\left.80^{\circ} \mathrm{C}\right)$ or $0.25 \mathrm{~g}$ of inulin $\left(60 \mathrm{~min}\right.$ at $\left.80^{\circ} \mathrm{C}\right)$, the 5 -HMF yields were $44.8 \%$ and $59.2 \%$, respectively. More importantly, the $\mathrm{CM}-\mathrm{SO}_{3} \mathrm{H}$ and [BMIM][Cl] system showed high stability and could be reused between five and eight times with minimal loss of catalytic activity.

$\mathrm{CM}-\mathrm{SO}_{3} \mathrm{H}$ is a promising catalyst for the acid-catalysed conversion of biomass into value-added chemicals. In partic-

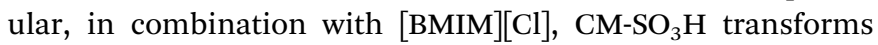
fructose-based carbohydrates into 5-HMF.

\section{Conflicts of interest}

There are no conflicts to declare.

\section{Acknowledgements}

The authors are grateful for financial support provided by the National Key Research and Development Program (Grant No. 2017YFD0801500).

\section{Notes and references}

1 L. Filiciotto, A. M. Balu, J. C. V. d. Waal and R. Luque, Catal. Today, 2018, 302, 2-15.

2 L. Cao, I. K. M. Yu, S. S. Chen, D. C. W. Tsang, L. Wang, X. Xiong, S. Zhang, Y. S. Ok, E. E. Kwon, H. Song and C. S. Poon, Bioresour. Technol., 2018, 252, 76-82.

3 M. N. Catrinck, E. S. Ribeiro, R. S. Monteiro, R. M. Ribas, M. H. P. Barbosa and R. F. Teófilo, Fuel, 2017, 210, 67-74.

4 X. Xiong, I. K. M. Yu, S. S. Chen, D. C. W. Tsang, L. Cao, H. Song, E. E. Kwon, Y. S. Ok, S. Zhang and C. S. Poon, Catal. Today, 2018, 314, 52-61.

5 Y. Dou, S. Zhou, C. Oldani, W. Fang and Q. Cao, Fuel, 2018, 214, 45-54.

6 H. Zhao, J. E. Holladay, H. Brown and Z. C. Zhang, Science, 2007, 316, 1597-1600.

7 D. Steinbach, A. Kruse, J. Sauer and P. Vetter, Energies, 2018, 11, 645-660.
8 Y. Zhang, M. Liu, J. Zhao, K. Wang, M. Meng and Y. Yan, ChemistrySelect, 2018, 3, 5950-5959.

9 J. Wang, Z. Zhang, S. Jin and X. Shen, Fuel, 2017, 192, 102107.

10 F. Parveen and S. Upadhyayula, Fuel Process. Technol., 2017, 162, 30-36.

11 Y. Román-Leshkov, J. N. Chheda and J. A. Dumesic, Science, 2006, 312, 1933-1937.

12 D. Garcés, E. Díaz and S. Ordóñez, Ind. Eng. Chem. Res., 2017, 56, 5221-5230.

13 A. Deng, Q. Lin, Y. Yan, H. Li, J. Ren, C. Liu and R. Sun, Bioresour. Technol., 2016, 216, 754-760.

14 M. Ventura, A. Dibenedetto and M. Aresta, Inorg. Chim. Acta, 2018, 470, 11-21.

15 B. Agarwal, K. Kailasam, R. S. Sangwan and S. Elumalai, Renewable Sustainable Energy Rev., 2018, 82, 2408-2425.

16 H. Mo, X. Chen, X. Liao and T. Zhou, J. Cent. South Univ., 2017, 24, 1745-1753.

17 C. Antonetti, A. M. R. Galletti, S. Fulignati and D. Licursi, Catal. Commun., 2017, 97, 146-150.

18 W. Li, T. Zhang, H. Xin, M. Su, L. Ma, H. Jameel, H. Chang and G. Pei, RSC Adv., 2017, 7, 27682-27688.

19 R. Liu, J. Chen, X. Huang, L. Chen, L. Ma and X. Li, Green Chem., 2013, 15, 2895-2903.

20 R. Zhong and B. F. Sels, Appl. Catal., B, 2018, 236, 518-545. 21 R. Zhong, F. Yu, W. Schutyser, Y. Liao, F. d. Clippel, L. Peng and B. F. Sels, Appl. Catal., B, 2017, 206, 74-88.

22 X. Qi, N. Liu and Y. Lian, RSC Adv., 2015, 5, 17526-17531.

23 F. Huang, W. Li, Q. Liu, T. Zhang, S. An, D. Li and X. Zhu, Fuel Process. Technol., 2018, 181, 294-303.

24 X. Guo, Q. Cao, Y. Jiang, J. Guan, X. Wang and X. Mu, Carbohydr. Res., 2012, 351, 35-41.

25 X. Du, J. Zhang, Y. Wang and Y. Qu, Catalysts, 2017, 7, 245256.

26 K. Nakajima and M. Hara, ACS Catal., 2012, 2, 1296-1304.

27 D. Ni, L. Wang, Y. Sun, Z. Guan, S. Yang and K. Zhou, Angew. Chem., Int. Ed. Engl., 2010, 49, 4223-4227.

28 Z. Guan, L. Liu, L. He and S. Yang, J. Hazard. Mater., 2011, 196, 270-277.

29 Z. Wang, D. Cheng, C. Chen and K. Zhou, Carbon, 2018, 136, 54-62.

30 G. Chen, G. Song, W. Zhao, D. Gao, Y. Wei and C. Li, Chem. Eng. J., 2018, 352, 64-70.

31 F. Huang, Y. Su, Y. Tao, W. Sun and W. Wang, Fuel, 2018, 226, 417-422.

32 A. M. d. C. Lopes and R. Bogel-Łukasik, ChemSusChem, 2015, 8, 947-965.

33 A. M. d. C. Lopes, K. G. João, D. F. Rubik, E. Bogel-Łukasik, L. C. Duarte, J. Andreaus and R. Bogel-Łukasik, Bioresour. Technol., 2013, 142, 198-208.

34 Q. Cao, X. Guo, S. Yao, J. Guan, X. Wang, X. Mu and D. Zhang, Carbohydr. Res., 2011, 346, 956-959.

35 H. Liu, Y. Wang, W. Ma, H. Wang, D. Wang, W. Jiang, M. Zhang, C. Zhou and H. Li, Chem. Pap., 2017, 71, 15411549.

36 V. Kempter and B. Kirchner, J. Mol. Struct., 2010, 972, 22-34. 
37 C. Moreau, A. Finiels and L. Vanoye, J. Mol. Catal. A: Chem., 2006, 253, 165-169.

38 F. Guo, Z. Fang and T. J. Zhou, Bioresour. Technol., 2012, 112, 313-318.

39 A. H. Jadhav, H. Kim and I. T. Hwang, Catal. Commun., 2012, 21, 96-103.

40 J. N. Chheda, Y. Román-Leshkov and J. A. Dumesic, Green Chem., 2007, 9, 342-350.

41 H. Xin, T. Zhang, W. Li, M. Su, S. Li, Q. Shao and L. Ma, RSC Adv., 2017, 7, 41546-41551.

42 P. A. Russo, M. M. Antunes, P. Neves, P. V. Wiper, E. Fazio, F. Neri, F. Barreca, L. Mafra, M. Pillinger, N. Pinna and A. A. Valente, Green Chem., 2014, 16, 4292-4305.

43 Y. Zhang, Y. Shen, Y. Chen, Y. Yan, J. Pan, Q. Xiong, W. Shi and L. Yu, Chem. Eng. J., 2016, 294, 222-235.

44 X. Qi, H. Guo, L. Li and J. R. L. Smith, ChemSusChem, 2012, 5, 2215-2220.
45 D. Yamaguchi, K. Watanabe and S. Fukumi, Sci. Rep., 2016, 6, 20327-20334.

46 M. Watanabe, Y. Aizawa, T. Iida, R. Nishimura and H. Inomata, Appl. Catal., A, 2005, 295, 150-156.

47 Z. Wang, H. Li, C. Fang, W. Zhao, T. Yang and S. Yang, Energy Technol., 2017, 5, 2046-2054.

48 S. K. R. Patil and C. R. F. Lund, Energy Fuels, 2011, 25, 47454755.

49 X. Qi, M. Watanabe, T. M. Aida and J. R. L. Smith, Green Chem., 2009, 11, 1327-1331.

50 M. Walia, U. Sharma, V. K. Agnihotri and B. Singh, RSC Adv., 2014, 4, 14414-14418.

51 Z. Ma, H. Hu, Z. Sun, W. Fang, J. Zhang, L. Yang, Y. Zhang and L. Wang, ChemSusChem, 2017, 10, 1669-1674.

52 S. Kang, J. Ye, Y. Zhang and J. Chang, RSC Adv., 2013, 3, 7360-7366.

53 X. Qi, M. Watanabe, T. M. Aida and J. R. L. Smith, Green Chem., 2010, 12, 1855-1860. 